\title{
Ocular Findings in Patients with COVID- 19: Impact on Eye Banking [Letter]
}

\author{
Loïc Hamon (iD) \\ Tarek Bayyoud (D) ${ }^{2}$ \\ Berthold Seitz $\mathbb{D}^{1}$ \\ 'Department of Ophthalmology, Saarland \\ University Medical Center (UKS), \\ Homburg/Saar, Germany; ${ }^{2}$ Department \\ of Ophthalmology, University of \\ Tübingen, Tübingen, Germany
}

Correspondence: Loïc Hamon

Department of Ophthalmology, Saarland University Medical Center (UKS),

Kirrbergerstraße 100, Bld. 22, Homburg/

Saar, 66421, Germany

Tel +49 I742I69806

Fax +49 684II622400

Email loic.hamon@uks.eu

\section{Dear editor}

With great interest, we have read the article by Qu et al on severe acute respiratory syndrome coronavirus 2 (SARS-CoV-2) transmission through the ocular route. ${ }^{1} \mathrm{We}$ would like to discuss the triggered impact on eye banking and corneal transplantation.

The authors reported a high potential of SARS-CoV-2 contagion of the ocular surface through hand-eye contact and aerosols and a possible transfer to other systems via nasolacrimal route or blood metastasis. ${ }^{1}$ No mention has been made of possible SARS-CoV-2 contagion through ocular tissue transplantation, such as corneal transplantation, which may constitute another form of "ocular route".

This question, which is particularly concerning for eye banks, was already investigated by Casagrande et al. They reported RNA traces in 6 out of $11(55 \%)$ corneas of deceased donors with SARS-CoV-2 activity (viremia), or recent exposure. Nevertheless, no presence of viral structural protein could be confirmed in any corneal tissue. ${ }^{2}$ Another study conducted by Bayyoud et al on 10 bulbi could not detect any signs of SARS-CoV-2 in neither conjunctiva, nor anterior chamber fluid nor corneal tissues of infected donors. ${ }^{3}$ These findings suggest that, even in donors with pre-mortem acute SARS-CoV-2 infection, the rate of contaminated ocular tissues post-mortem is very low and without any strong evidence of viral replicability. Therefore, the risk for SARS-CoV-2 contagion via corneal transplantation through the "ocular route" is minor.

Being part of university corneal transplantation centers with on-site eye bank, we have routinely pursued explanting donor corneas during the pandemic, excluding SARS-CoV-2 positive or coronavirus disease 2019 (COVID-19) suspicious donors in accordance to European Eye Bank Association (EEBA) and Global Alliance of Eye Bank Associations (GAEBA) recommendations. While most of our donors have been tested with reverse-transcriptase-polymerase-chain -reaction (RT-PCR) for SARS-CoV-2 pre-mortem during the inpatient stay (and were confirmed "negative"), a substantial proportion of donors resulted from the cooperation with our Institute for Anatomy (body donors) or with external institutions and had an unknown SARS-CoV-2 status. None of the postmortem RT-PCR of the nasopharyngeal (0/199) and conjunctival swabs of these donors (0/262), performed - after flushing the ocular surface with 5\% povidone-iodine for 5 minutes - in conjunction with the excision of $15 \mathrm{~mm}$ 
corneoscleral buttons from all post-mortem donors since April 2020, revealed any presence of SARS-CoV-2. We therefore conclude that the risk of SARS-CoV-2 contamination via corneal transplantation, after exclusion of infected or highly suspicious donors, is very low to absent.

In 2020, many eye banks drastically reduced or even ceased their activity as a preventive measure during the pandemic. ${ }^{4}$ Facing the lack of evidence for post-mortem SARS-CoV-2 activity or replicability in ocular tissues, and considering the increasing cumulative number of patients needing a corneal tissue for transplantation, we recommend to continue collection of all available corneas, as long as the appropriate precautions are taken. Considering the possibility of ocular transmission through "ocular route", only tissue from donors with confirmed SARSCoV-2 infection or with a high clinical suspicion for COVID-19 should not be selected for transplantation purposes. $^{5}$

\section{Disclosure}

The authors report no conflicts of interest in this communication.

\section{References}

1. Qu JY, Xie HT, Zhang MC. Evidence of SARS-CoV-2 transmission through the ocular route. Clin Ophthalmol. 2021;15:687-696. doi: $10.2147 /$ OPTH.S295283

2. Casagrande M, Fitzek A, Spitzer MS, et al. Presence of SARS-CoV-2 RNA in the cornea of viremic patients with COVID-19. JAMA Ophthalmol. 2021;139(4):383-388. doi:10.1001/jamaophtha Imol.2020.6339

3. Bayyoud T, Iftner A, Iftner T, et al. Absence of severe acute respiratory syndrome coronavirus-2 RNA in human corneal tissues. Cornea. 2021;40(3):342-347. doi:10.1097/ICO.0000000000002479

4. Trigaux C, Salla S, Schroeter J, et al. SARS-CoV-2: impact on, risk assessment and countermeasures in German Eye Banks. Curr Eye Res. 2021;46(5):666-671. doi:10.1080/02713683.2020.1828487

5. Bayyoud T, Iftner T, Bartz-Schmidt KU, et al. First results of investigations of SARS-CoV-2 RNA in human corneal tissue. Ophthalmologe. 2021;118(S1):78-80. doi:10.1007/s00347-02001254-8

\footnotetext{
Dove Medical Press encourages responsible, free and frank academic debate. The content of the Clinical Ophthalmology 'letters to the editor' section does not necessarily represent the views of Dove Medical Press, its officers, agents, employees, related entities or the Clinical Ophthalmology editors. While all reasonable steps have been taken to confirm the content of each letter, Dove Medical Press accepts no liability in respect of the content of any letter, nor is it responsible for the content and accuracy of any letter to the editor.
}

Clinical Ophthalmology

\section{Dovepress}

\section{Publish your work in this journal}

Clinical Ophthalmology is an international, peer-reviewed journal covering all subspecialties within ophthalmology. Key topics include: Optometry; Visual science; Pharmacology and drug therapy in eye diseases; Basic Sciences; Primary and Secondary eye care; Patient Safety and Quality of Care Improvements. This journal is indexed on PubMed
Central and CAS, and is the official journal of The Society of Clinical Ophthalmology (SCO). The manuscript management system is completely online and includes a very quick and fair peer-review system, which is all easy to use. Visit http://www.dovepress.com/ testimonials.php to read real quotes from published authors. 